\title{
Introduction: Hans Christian Andersen, best of story tellers
}

\section{Helle Porsdam}

On 1 April 2005 at the University of Southern Denmark in Odense, Professor Harold Bloom came close to adding one more name to his list of the greatest and most original authors of the Western literary tradition - that of the Danish writer Hans Christian Andersen (1805-75). The famous Yale professor and author of numerous books on literary criticism had been invited to Odense, Denmark to deliver the Hans Christian Andersen Academy Lecture 2005 and to receive the Hans Christian Andersen Award 2005. The award of 50000 euros was given to Harold Bloom in Andersen's native town of Odense with much pomp and circumstance on 2 April, the day that all of Denmark celebrated the 200th anniversary of the most famous Danish writer of all times.

There is perhaps a certain irony in the fact that it was Harold Bloom who became the recipient of this award. Hans Christian Andersen is not among the handful of writers who make up the Bloomian literary canon. The writers that constitute The Western Canon: The Books and School of Ages, as Bloom called one of his most controversial books from 1994, are 'strong poets' - those who have been strong enough to transcend that 'anxiety of influence' which all writers feel toward their literary precursors. The strongest of them all is Shakespeare, who is Bloom's hero. Shakespeare not only defined for the Western world the standards by which we judge all literature; he also defined for us what it means to be human. Modern literature has not added very much to what people could have already learned from reading Shakespeare, and Shakespeare has therefore become the precursor with whom all subsequent writers have had to contend.

Originality in literature for Bloom thus pretty much means the strength to kill off one's precursors - to not just become copies of these precursors. To what extent did Hans Christian Andersen possess such originality? This was clearly one of the more important questions that had presented themselves to Bloom when he agreed to deliver his talk in Odense. Having never done much work on Andersen before, he considered it a challenge to think the Danish writer into - or at least relate him to - his canon. He opened his lecture in this way: 
Andersen's prime precursors included Shakespeare and Sir Walter Scott, and his best work can be thought of as an amalgam of A Midsummer Night's Dream and the almost as magnificent 'Wandering Willie's Tale' from Scott's Redgauntlet, with a certain admixture of Goethe and of the 'Universal Romanticism' of Novalis and E.T.A. Hoffman. Goethean 'renunciation' was central to Andersen's art, which truly worships only one god, who can be called Fate. Though Andersen was a grand original in his fairy tales, he eagerly accepted from folklore its stoic acceptance of fate. ${ }^{1}$

Later in his talk Bloom emphasized, though, that it was only Andersen's fairy tales - and not his novels, dramas, poetry and travel writings - that 'are, for the most part, unique works that transcend their sources ... Only in May 1835 did he find his own genre, the visionary stories that have been as widely translated and circulated as the Bible, Shakespeare, and Don Quixote'. Now, to the list of writers and works already mentioned as Andersen's 'prime precursors', Bloom added folk tales and The Arabian Nights.

Having thus established Andersen as an original writer - that is, not just a copyist of the writing of those that came before him - Bloom then attempted to pinpoint the characteristics of this originality. 'Defin[ing] precisely the qualities of Andersen's stories that go on making them imperishable' turned out not to be quite so easy though. Andersen's project in life, Bloom claimed, was 'how to remain a child in an ostensibly adult world'. 'Childlike in Denmark, Andersen was childish abroad'; yet, if he was a visionary story teller, 'his fairy-realm was malign'. Andersen may have invented what in the last two centuries has been called 'children's literature', but it is a literature that is full of atrocious and cruel creatures. Andersen's is not a benign and beautiful universe - 'after some early stories he is no more available just to children than are Kafka and Gogol. Rather, Andersen wrote for extraordinarily intelligent children of all ages, from nine to ninety'. Ultimately, this children's writer who did not really write for children, but for adults, defies interpretation - 'I believe', said Bloom, 'that we still have not learned how to read him ... if there is an aesthetic wholly equipped to analyze Andersen's peculiar power, I have not encountered it'.

\section{TRUST THE ORIGINAL, NOT THE TRANSLATION?}

Bloom's amazement at discovering the grown-up side of Hans Christian Andersen's fairy tales, and the role that this amazement may have played in his concluding that Andersen defies interpretation, is interesting. Anybody with enough knowledge of the Danish language to be able to read Andersen in the original is aware that Andersen wrote stories that might be read aloud to children, but that were designed in such a way as also to be of interest to the grown-up(s) reading them aloud. The difference between the way in which 
Andersen is perceived by his countrymen and by readers who cannot read him in his own language may well have something to do with his translators. 'The bad translations of H.C. Andersen's fairy tales have given the Englishspeaking world a distorted and one-sided view of H.C. Andersen', complained one of the first Danish scholars to write about Andersen's reception in the English-speaking world, Elias Bredsdorff. ${ }^{2}$ And he continued:

People know that he has fantasy and originality, but that he was an inspired artist only very few Englishmen realize. The English understand that [Andersen's] countrymen use him commercially in the tourist industry, but they are surprised that he has been assigned a big and significant place in literature. Andersen's fairy tales are still appreciated by English children, but they outgrow him and are not tempted to rediscover him when they grow up - understandably enough perhaps, considering the boring way in which [the tales] are often presented. (Bredsdorff 1954, 520)

Bredsdorff may not have been quite fair in his assessment of the work done by Andersen's translators, however. Instead of claiming that miserable translations are to blame for Andersen being read only by children, argues Viggo Hjørnager Pedersen, 'one might just as well claim that the translations have to a large extent been shaped by their being regarded as children's literature' (Hjørnager Pedersen 2004, 15-16). Besides, Andersen's influence on English literature is much greater than Bredsdorff's condemnation makes us think. Andersen is 'to all intents and purposes an English writer, read by millions of people who do not understand a word of Danish, and exerting more influence on English children's writing than any native Briton until Lewis Carroll' (ibid. 16). Danes may well regret this, but they would do well to remember that to millions of people around the world - Andersen having, as Bloom noted, been translated almost as widely and into as many different languages as the Bible itself - Andersen is known only in translation, that is, as a copy.

'Whose Ducklings Are They Anyway?', Hjørnager Pedersen therefore asks, and the story he tells of the English translations of Andersen's tales and stories is a very interesting one. The first of Andersen's works to appear in English was The Improvisatore. It was published in England in 1845 and had been translated by Mary Howitt - from the German. Andersen's novel had become a big hit in Germany, and Howitt, who was living in Germany between 1840 and 1843, seems to have known some Swedish, but no Danish. In this, Howitt was no different from the majority of English translators who 'worked either directly from the German, or used German translations as cribs' (ibid. 18). The Improvisatore got very favourable reviews in the English press. 'As a book of pleasing travels and admirable reflections we know of none better; and we can sincerely recommend it to our readers,' wrote a reviewer in the London Journal, for example (quoted in Bredsdorff 1954, 434). 
The real turning-point in Andersen's career in the English-speaking world came only a couple of years later, and what made Andersen a household name in England were not the two novels that followed The Improvisatore so much as the tales and stories that were translated into English. During 1846-47 only a few years later than they appeared in Danish - nine different selections of Andersen's stories and tales by six different translators appeared in English. The 44 stories and tales for which Andersen received instant fame are more or less the same stories and tales for which he is known to this day in the Englishspeaking world (and through the English-speaking world to the rest of the world, too) - 'The Princess on the Pea', 'The Little Mermaid', 'The Tinderbox', 'The Emperor's New Clothes', 'The Wild Swans', 'The Swineherd', 'The Ugly Duckling' and 'The Nightingale', to mention just a few. Many of his later stories and tales were not exactly children's stuff - they are the ones that contain the cruelty on which Harold Bloom commented and which he did not really know what to do with. These later tales appeared in one or two editions, but at the same time the far more popular 'children's stories' from his earlier years 'were republished, pirated, and adapted in a great and ever growing number of versions. The result was that the Andersen people knew toward the end of the century, and the Andersen they know today, came to be perceived as the author of somewhere between 5 and 50 tales, not of the 156 that he actually wrote' (Hjørnager Pedersen 2004, 73-4).

Early translators like Mary Howitt were partly to blame for relegating Andersen to the nursery, but they were operating under certain moral and practical constraints. Victorian prudery as to what was proper for grown-ups to read aloud to children was one such constraint. Books written for young children should neither be too frightening nor too violent, and sexual overtones or references definitely had to be toned down. Andersen's work, of course, was full of violence and did contain many more or less overt sexual references. Furthermore Andersen's often class-related humour was felt to be too blunt or critical of the political status quo. Hjørnager Pedersen mentions as an example of this a particular translation of 'The Tinderbox'. Whereas Andersen's queen is very human and down-to-earth - she 'could do more than just ride in a coach' (directly translated from the Danish) - the queen in the translation 'does not just ride in a coach, but "looks grand and condescending", which rather undermines the idea of her being a common-sense, practical woman' (ibid. 105). To this was added more practical considerations concerning the tastes of the publishers and buyers of Christmas books for children. This was a genre that became very popular during the nineteenth century, and publishers considered it the ideal venue for Andersen's work. Being a translator was hard work and did not pay all that well, after all, and for all of these reasons translators found themselves forced into adjusting Andersen's stories to prevailing tastes. 
What then of later translations? According to Hjørnager Pedersen, later translations - even those that appeared well into the twentieth century and those that are published today - seem to rely heavily on the earlier translations (which in turn relied, as we saw, on German translations). One might even speak of a 'family of translations', an interdependence 'between the majority of the English translations, which seem to make up a large family of texts. Some translators obviously paraphrased their predecessors - and in some cases, this was already known - but, in addition, many more or less independent translators have borrowed from the tradition, so that it is difficult to find a modern edition that is not in some way or other indebted to older ones' (ibid. 353). If we add to this the fact mentioned above that to most of the world, Andersen is known in 'an imitation, a translation that is [sometimes] so free that it begins to look like a new work' (ibid. 17), the line between that which is the original and that which is the copy in relation to Hans Christian Andersen starts to become very blurred indeed.

\section{HANS CHRISTIAN ANDERSEN AND COPYRIGHT}

Andersen's first work started appearing in Denmark in the 1830s. Throughout his lifetime his stories and tales were translated as they appeared. In fact some of them were published in English even before they appeared in Danish. Bredsdorff lists 18 stories, two novels, one travel book and the definitive edition of Andersen's autobiography as having appeared in English before they appeared in Danish (Bredsdorff 1954, 621-2; Hjørnager Pedersen 2004, 73).

Inevitably, some translations were better than others. Of this however Andersen could not himself be the judge. While he was quite good at German and French, he did not speak English very well, and even though he attempted on more than one occasion to learn the language, he never succeeded. How difficult it could be to engage in conversation with Andersen in English, the American writer J. Ross Brown described in his book The Land of Thor, from 1867. When he visited Denmark in 1866, he called on Andersen, who tried to tell him about his latest fairy tale, 'The Beetle':

'Have you seen my last - the - what do you call it in English? - a little animal -' 'Mouse,' I suggested.

'No, not a mouse; a little animal with wings.'

'Oh, a bat!'

'Nay, nay, a little animal with wings and many legs. Dear me! I forget the name in English, but you certainly know it in America - a very small animal!'

In vain I tried to make a selection from all the little animals of my acquaintance with wings and many legs. The case was getting both embarrassing and vexatious. At length a light broke upon me. 
'A mosquito!' I exclaimed, triumphantly.

'Nay, nay!' cried the bothered poet; 'a little animal with a hard skin on its back. Dear me, I can't remember its name!'

'Oh, I have it now,' said I, really desirous of relieving his mind - 'a flea!'

At this the great improvisator scratched his head, looked at the ceiling and then at the floor, after which he took several strides up and down the room, and struck himself repeatedly on the forehead. Suddenly grasping up a pen, he exclaimed, somewhat energetically, 'Here! I'll draw it for you;' and forthwith he drew on a scrap of paper a diagram, of which the accompanying engraving is a fac-simile.

'A tumble-bug!' I shouted, astonished at my former stupidity.

The poet looked puzzled and distressed. Evidently I had not yet succeeded. What could it be?

'A beetle! A beetle!' I next ventured to suggest, rather disappointed at the result of my previous guess.

'A beetle! A beetle! - that's it; now I remember - a beetle!' and the delighted author of 'The Beetle' patted me approvingly on the back, and chuckled gleefully at his own adroit method of explanation.'

(quoted in Bredsdorff 1954, 273-4)

At the time of this encounter, Andersen was 61. He was world famous and received fan calls and letters from all corners of the world. One fan was another American by the name of Horace E. Scudder. Scudder was an editor with the Riverside Magazine for Young People, which was published out of Boston, and he first wrote to Andersen in 1862: 'I assure you it is with no small pleasure that I write thus to one who has doubtless many honourable insignia, but who is to me and to all my fellow children in America, young and old, simply Hans Christian Andersen, best of story tellers' (Hersholt 1948, 18). Scudder received no answer to this gracious letter. In fact, he had to write three more letters to Andersen before the latter finally wrote back. What prompted the Danish writer to answer Scudder's fourth letter, dated 13 March 1868, was Scudder's proposition of 'an arrangement', according to which Andersen would receive $\$ 500$ for 12 new stories to be published in the Riverside Magazine. 'It is understood', Scudder wrote, 'that these stories shall not have been published in English beforehand' (ibid. 23).

To Andersen, Scudder's offer of remuneration for his work was highly welcome. He did have slight misgivings at first about the Riverside Magazine being the right venue for his stories: 'On a cursory perusal of the Riverside Magazine I must confess that it is my impression that the greater part of it is written for very young people, and though I know that my tales are read by young and old, and that the former enjoy what I would call the exterior, the latter the inner part, I think that my stories are not entirely on their right place in the said Magazine' (ibid. 25). In the end however the thought of finally getting paid for his translated work won him over, and he granted Scudder a near monopoly of the translation rights for new stories: 'I oblige myself to take care that any new stories or tales, which I may send to the Riverside Magazinge 
are not published, neither in Danish nor in any other language until three months after they have been sent to you' (ibid. 31).

Between 1868 and 1875, Andersen received about $\$ 2200$ in royalties through Scudder from his American publishers (ibid. 11). Before 1868, he had received nothing at all from the United States. His royalties from England amounted to $£ 368$ - a ridiculously small amount, which can only be accounted for by the fact that there was no international copyright protection during Andersen's lifetime (Bredsdorff 1954, 623). English and American publishers could - and indeed did - print whatever part of Andersen's oeuvre they wanted without paying him anything. It was only with the Berne Convention for the Protection of Literary and Artistic Works in 1886 that an author's right to be paid for translations of his or her work was established. When Andersen wrote to a friend in 1836 that, 'unfortunately I belong to such a small nation that even though my work is among the most well-read of works, it will hardly be able to feed me' (ibid. 622), he hardly knew how prophetic his words would be.

Paradoxically, furthermore, as Andersen's fame grew in England and later also the United States, it became harder to interest respectable publishers in publishing the later stories in an English translation. The more popular Andersen became, the more likely it was that cheap pirate editions would be published, and the lack of protection for the author, the translator as well as the publisher of work done by non-English (or non-American) writers created problems for the more serious publishing companies who wanted to treat 'their' authors fairly. One interesting case in point is Richard Bentley, the first English publisher to publish Andersen's work. In 1846 Bentley offered Andersen $£ 50$ for each work of more than 320 pages that the writer might yet produce - provided that Andersen himself paid for the translation of such a work, and that it had been published in neither Denmark nor Germany.

A few years later though, in 1850, Bentley had to renege on his offer:

I regret to tell you that the last book I published of yours did not succeed - in fact it left me with a loss. This I attribute, beyond public caprice, to the present state of the Copyright Act, which does not protect a publisher in what I have always considered his just rights - that is, the Law at present here will not allow the right of a foreigner to have copyright here, nor to assign it. The effect of this is, that Publishers hesitate to give money when their work may be pirated, but it also operates injuriously inasmuch as the booksellers will not purchase on speculation a book at a fair price, when a cheaper edition may appear in the market next day. In this state of things - for this is a recent decision - I do not know what to do - it clearly will not be in my power to purchase copyright. ${ }^{3}$

Bentley pretty much lost interest in dealing with foreign writers when he lost a lot of money in 1855, because the House of Lords rejected his claim to the right to publish a number of American writers with whom he had signed a contract. The subject, he wrote to Andersen, 'sickens me': 
In consequence of the decision of the House of Lords, declaring that no foreigner had copyright in English, I lost $1000 £$ a year. All the property which I had acquired in this class of works was declared valueless! property for which I paid upwards of $£ 23000$ ! - Had the House been content with making the law prospective it would not have been unjust, but to sacrifice an individual who has acquired this property by regular purchase under the sanction of repeated Decisions of all our Courts (that a foreigner first publishing here did possess copyright) - was and is a monstrous wrong, and calls for redress. But what can an individual do against such fearful odds - and so I am sacrificed for the public good! Such a monstrous wrong would not be done, I believe, even in Russia, but for England, which professes to encourage literature, and seeks to draw all learned men and all men eminent for art or science to her, thus to refuse their claim to the fruit of their labours, it is a high crime against the principles she vaunts her desire to carry out. The subject sickens me, so I will quit it. (ibid. 191-2)

When a collection of Andersen's tales and stories was published in Denmark in 1872, Andersen sent a copy of the book to Edmund Gosse, who subsequently asked the Danish writer's permission to translate it and find a publisher for it in England. He received Andersen's permission, but wrote to Andersen the following year that his efforts on the latter's behalf had been in vain:

No one here in London will risk the publication of a translation of your last stories. Perhaps this will surprise you as much as it did me, but the reason of it lies in the extreme popularity of your works amongst us. Unless a very cheap and common edition were brought out, - and this would not be worth your while or mine, - the publishers fear that the translation would at once be pirated by other publishinghouses, and they themselves would lose their profits. Added to this is the difficulty of an already-existing translation in America. You know there is no copyright-treaty between England and Denmark, or between England and America, so your works are open to double danger. (ibid. 299-300)

Andersen died two years later, in 1875, and thus never saw the work done by Victor Hugo and other authors and publishers, organized in the International Literary Association, towards an international conference on copyright. Convinced that something had to be done about a copyright situation that protected the copyrights of a state's own citizens, but allowed the violation of copyrights held by citizens of other countries, members of the International Literary Association persuaded the president of the Swiss Federal Council to host a diplomatic conference in Berne in September 1884. This was the first time that representatives from different governments worked together on a draft agreement. Two more years were needed for negotiations before the Berne Convention could be signed on 9 September 1886 by ten countries. Great Britain, Germany and France were among the signatories but not the United States, which only joined the Berne Union in 1989 (MarlinBennett 2004, 53-4). 
After the Berne Convention, which itself has seen several revisions, other conventions and treaties have followed, all of which have strengthened the copyrights of authors and publishers. In 1970 the World Intellectual Property Organization (WIPO) was founded as an independent international organization. It became a specialized agency of the United Nations in 1976 and has been instrumental in institutionalizing rules representing the interests of the dominating parties in an increasingly global trading system. Twenty years later, the WIPO Copyright Treaty was signed. It builds on the provisions of the Berne Convention and revisits the protection of copyright in light of the challenges posed by the Internet and related digital advances (ibid. 56). Throughout, the trend has been toward an ever greater commodification and privatization of copyrights, the 'winners' being the global media companies, and the 'losers' being the general public and lesser-known authors who neither wish nor know how to write the sort of best-selling novels on display in bookstores in every major international airport.

What would Hans Christian Andersen have thought of this trend? While probably happy finally to be able to make some real money, my guess is that he would have agreed with many scholars - and this includes several of the scholars contributing to this book - that copyright is not and should not be considered as 'property'. It is, rather, 'a specific state-granted monopoly issued for particular policy reasons' (Vaidhyanathan 2001, 253). Andersen could not have anticipated the tensions coming to the fore a hundred years after his death between market interests and privacy, and between commodification and the commons. Nor could he have foreseen the questions that, as Renée Marlin-Bennett puts it, 'remain central to what should be an ongoing global debate' in the Information or Digital Age:

Who is making the rules about property rights? How are the rules being made? Are protections for rights holders strong enough? Do we need more rights and betterenforced rights? How is the public interest protected? Are we preserving a global knowledge commons? Are we allowing people to control the flow of information in ways consistent with their own needs and those of the public? (Marlin-Bennett 2004, 249)

It is these and related questions that the contributors to this book take up and discuss possible answers to. The idea to look at the issue of copyright against the background of Hans Christian Andersen and his work was fostered in the autumn of 2004 as the bicentennial of his birth was coming up. Professor Lawrence Lessig preceded Harold Bloom; on 4 November he delivered the Hans Christian Andersen Academy Lecture 2004 at the University of Southern Denmark in Odense on '(Re)creativity: How Creativity Lives'. Present on that occasion were the other contributors to this book who met again the following day to discuss 'Hans Christian Andersen and Copyright'. 
As it turned out, Andersen presented an ideal focus and/or point of departure for such copyright discussions.

\section{THE EIGHT CHAPTERS}

The first chapter is an adaptation of the lecture Lawrence Lessig gave in November 2004 at the University of Southern Denmark in Odense. As the title indicates, Lessig is concerned about how creativity lives - how culture gets created and then gets spread. Strictly speaking, he argues, all culture is remix - creative work being produced by some author, say Hans Christian Andersen, 'mixing bits of culture and his own creativity together'. Most of us are aware of the way in which writers remix and reuse the work of their precursors; what we may be less aware of is that readers also remix. Lessig reminds us that 'every act of consuming culture is an act of constructing culture. Through both, cultures get made.'

With the emergence of digital technology within the past 15 years, the reader now has immediate access to cultural sources of all kinds. While the new technology has empowered the individual reader and has created a more democratic form of speech from which society as a whole benefits, the use of the Internet has also turned every act into a copy. Actions that were previously free have now become regulated, even illegal. Remixing by using digital technology 'is rendered illegal, because in a world where all uses produce a copy, and in a world where all copies are copies of presumptively copyrighted material, one needs permission first, and this permission is not coming'.

The way to go, says Lessig, is not to reject copyright law altogether, but rather to find ways to fit copyright law to the digital technology. His own attempt to do so involves the non-profit corporation Creative Commons that has been internationalized through the iCommons Project. The idea is to provide each individual creator with a choice of licence. Depending on the licence chosen, the creator can limit certain commercial uses of the creative work in question, for example, just as he or she can permit or not permit modifications of the work. This sort of arrangement, argues Lessig, encourages cultural remix without destroying the underlying regime of intellectual property.

The other eight contributors to this book share Lawrence Lessig's concern about the present state of copyright law and the way in which it threatens the remix of culture and creativity. Whether or not to remain within the underlying regime of intellectual property law, and what sort of reforms are needed if we do decide to remain within this regime - these fundamental questions form the subtext for these eight contributors, just as they do for Lessig. The second and third chapters by Stina Teilmann and Uma Suthersanen, respectively, give 
us a very useful historical survey of copyright law. In 'On real nightingales and mechanical reproductions', Stina Teilmann takes as her point of departure three of Hans Christian Andersen's stories - 'The Princess on the Pea' (1835), 'The Swineherd' (1842) and 'The Nightingale' (1844) - for an analysis of the way in which 'authenticity' became an important marker of value during the nineteenth century. For Andersen - as for other nineteenth-century writers - the important thing was to be 'authentic' or 'real', and the emphasis on 'authenticity' had important consequences for copyright law. Whereas copyright originally, in the early 1700 s, was an author's right in a material copy (the original) to make more material copies, the object of copyright (the work) came during the nineteenth century to be defined as 'immaterial'. 'This served to separate literary and artistic property entirely from the physical property of manuscripts and artworks, as well as from the physical objects of the copies of a "work" ' - a separation that "is crucial for modern copyright law'.

Uma Suthersanen looks at the genesis of international copyright law in 'Bleak House or Great Expectations? The literary author as a stakeholder in nineteenth-century international copyright politics'. As writers were becoming stakeholders with economic and societal interests that had to be protected domestically as well as internationally, they began lobbying for the establishment of reciprocal copyright protection between different states. Charles Dickens is a famous case in point. Dickens visited the United States in 1842, and during this visit he repeatedly advocated for the protection of British works and the protection of international copyright law. The jury is still out as to whether Dickens's motives were of a pecuniary kind or whether they were of a more lofty and idealistic kind. Suthersanen uses Dickens and his fight for copyright protection to trace both the interplay between nineteenth-century literary authors and copyright awareness, and the history of the entry of the United States into the world of international copyright law. 'The nineteenth century is', as she points out, 'an archive of many such issues.'

'Adaptations abound. Versions of Hans Christian Andersen's tales are countless', writes Leslie Kim Treiger-Bar-Am in 'Adaptations with integrity'. She looks at an author's right to control such adaptations and other modifications of literary, visual and musical artworks. More interested in an author's moral right of integrity than in the economic interest in copyright that may also give copyright owners control over derivative uses, Treiger-Bar-Am centres her analysis on UK law and its enactment of section 80 of the Copyright, Designs and Patents Act 1988. Her premise is that the moral right of integrity is a right of expression, arising directly from the principles and the case law of freedom of expression, and her argument is that 'modifications to all artforms, and of all types, ought potentially be actionable pursuant to the integrity right'. Like Lawrence Lessig, Treiger-Bar-Am also points to the reader or viewer as 
a potential modifier of an original work. Such a modifier is also an author and must be protected accordingly: 'Freedom of expression is both the justification for the author's integrity right and for defences to claims pursuant to the right.' The integrity rights spectrum thus ultimately requires 'a balancing of autonomies of expression of author, modifier and reader'.

In 'What might Hans Christian Andersen say about copyright today?', Fiona Macmillan points to copyright's failure to further creativity and culture as primarily due to the fact that "we have allowed the process of commodification to take over copyright without really asking what the costs and consequences of this commodification are'. The original rationale for copyright that it encourages the production of the cultural works that enable culture and democracy to develop - has been sadly misused to allow a build-up of private power over cultural output. One consequence of this copyright-facilitated aggregation of private power is that big 'media and entertainment corporations are able to act as a cultural filter, controlling what we can hear'. This ability to control and manipulate markets severely limits the range of cultural products on offer, thus effectively homogenizing world culture. Another major consequence is a loss of the commons or public domain. Corporate control of the commons not only limits the public's access to cultural works; it also limits the opportunity for resistance and critique of the political status quo. Even though attempting to surmise Andersen's attitude toward this picture of cultural homogenization and domination is 'a risky business', Macmillan concludes, 'Some disruption of the current copyright consensus might very well be a fitting tribute to Hans Christian Andersen'.

One area that illustrates the inappropriateness of the property paradigm within copyright law is traditional cultural expression. In 'Hans Christian Andersen and the protection of traditional cultural expressions', Michael Blakeney examines the agitation for the protection of traditional cultural expression as an artefact of the international intellectual property regime. He shows how this agitation originated with calls for the protection of folkloric works within the context of the Berne Convention and then under UNESCO, and how it has been adopted as a cause of action by groups of indigenous peoples. This is not unproblematic however. Using Andersen's first four tales - 'The Tinder Box', 'The Princess on the Pea', 'Little Claus and Big Claus' and 'Little Ida's Flowers', all published in 1835 - as an illustration of the way in which cultural creativity has always included folkloric borrowings, Blakeney cautions that 'An intellectual property regime which provides for the protection of traditional cultural creativity should also permit the natural development of culture through permissible borrowings'. He goes on to examine justifications for the protection of traditional cultural expression and concludes with a testing of these justifications by an examination of the situation in Australia, where this branch of the law is the most elaborated. 
Lee Davis's focus in 'Should the logic of "open source" be applied to digital cultural goods? An exploratory essay' is the economic role of copyrights for digital cultural goods. Digitization has made possible the expression of almost all cultural works in virtual form on the Internet; they are easily accessible to anyone, anywhere in the world. Davis is especially interested in 'the implications of one of the most compelling developments in recent years: that the copyright has inspired its own antithesis, with the growth of the "open source software" (OSS) movement'. With the new digital technology, readers and users can play around with and manipulate works of art of previous centuries, for example the works of Hans Christian Andersen. 'The results', she writes, 'might be highly creative. But they might just as easily be "mush". Whatever the case, the stories created would be far from Andersen's original work.' The question is therefore whether OSS, in its facilitation of continuous free public access to software innovations, jeopardizes the preservation of older works of art. Ultimately, 'solutions ... need to be found', Davis concludes, 'that both enable artists to maintain the integrity of their work, and enable other interested parties to experiment with these works in new ways'.

The solution to the problems outlined by Davis, as indeed to many other copyright-related problems, Marieke van Schijndel and Joost Smiers would argue, is simply to give up on copyright law altogether. In the last chapter of the book, 'Imagining a world without copyright: the market and temporary protection, a better alternative for artists and the public domain', van Schijndel and Smiers suggest a thought-experiment: that we join them in a journey into a world without copyright. It is, they acknowledge, not an easy thought-experiment to conduct; most of us find it very difficult to imagine a world without copyright. It may be worth our trouble though. Having discussed (in order then to dismiss) various models that have been presented as alternatives to the current copyright regime - one of which being Lessig's Creative Commons model - van Schijndel and Smiers propose a model of their own: the usufruct model. This is a civil law alternative to the Anglo-American notion of copyright as property - 'characteristic for usufruct is that one does not have the ownership of an item; however, one is entitled to the usage of the fruits of the item'. There are a number of practical matters that still need to be resolved with respect to the usufruct model, van Schijndel and Smiers admit, but the matter may well take care of itself in the end: 'With digitization in mind, our guess is that we will not have to wait much longer before the copyright system will crumble.'

\section{NOTES}

1. Harold Bloom, 'Trust the Tale, not the Teller'. Lecture given at the University of Southern 
Denmark on 1 April 2005 on the occasion of the 200th anniversary of Hans Christian Andersen. Not yet published. Manuscript in author's possession. The author wishes to thank Professor Bloom for having graciously given her a copy of his talk.

2. Bredsdorff (1954), p. 520 (my translation from the Danish - all subsequent translations from this book are my own).

3. Bredsdorff (1954), p. 624 - the story of Andersen and copyright in England and the United States is based on Bredsdorff, (1954), pp. 622-5.

\section{BIBLIOGRAPHY}

Bredsdorff, Elias (1954), H.C. Andersen og England [H.C. Andersen and England], Copenhagen: Rosenkilde \& Bagger.

Hersholt, Jean (1948), H.C. Andersen og Horace E. Scudder: En brevveksling [H.C. Andersen and Horace E. Scudder: An Exchange of Letters], Copenhagen: Gyldendal.

Hjørnager Pedersen, Viggo (2004), Ugly Ducklings? Studies in the English Translations of Hans Christian Andersen's Tales and Stories, Odense: University of Southern Denmark Press.

Marlin-Bennett, Renée (2004), Knowledge Power: Intellectual Property, Information, and Privacy (Ipolitics), Boulder, CO: Lynne Rienner Publishers.

Vaidhyanathan, Siva (2001), Copyrights and Copywrongs: The Rise of Intellectual Property and How It Threatens Creativity, New York: New York University Press. 